\title{
ВЛИЯНИЕ МЕТИЛОВОГО ЭФИРА 4-АМИНО-3-ФЕНИЛБУТАНОВОЙ КИСЛОТЫ CL-АРГИНИНОМ (МЕФАРГИН) НА ФИЗИЧЕСКУЮ РАБОТОСПОСОБНОСТЬ КРЫС ПОСЛЕ ХРОНИЧЕСКОЙ АЛКОГОЛЬНОЙ ИНТОКСИКАЦИИ
}

\author{
Ю.А. Смольнякова, Л.Е. Бородкина \\ Кафедра фармакологии и фармации Института НМФО, ВолгГМУ, \\ 400131, Россия, Волгоград, площадь Павших Борцов, д.1. \\ E-mail: smolnyakova.yul@mail.ru
}

DOI: 10.19163/MedChemRussia2021-2021-103

Длительное употребление алкоголя является основной причиной многих заболеваний и сопровождается снижением физической работоспособности [1]. В этой связи поиск веществ для коррекции данных нарушений является актуальным. Исследовановлияние производного ГАМК-соединения РГПУ-260 на физическую работоспособность крыс после хронической алкогольной интоксикации.

Эксперименты были проведены на 50 белых крысах-самках линии Вистар. Полупринудительную 6-месячную алкогольную интоксикацию вызывали заменой воды 10\% раствором этилового спирт с 5\% сахарозой. Были сформированы группы: 1 - интактная, не получавшая алкоголь; 2 - контрольная с ХАИ, которой после 6 месячной алкоголизации вводили физиологический раствор; 3, 4 опытные группы, животные с ХАИ, получавшие после отмены алкоголя мефаргин -25 мг/кг и препарат сравнения фенотропил -25 мг/кг соответственно; вещества вводили внутрибрюшинно 1 раз в день в течение 14 дней после отмены этанола. Мышечную силу определяли в тестах «удержание тела на горизонтальном веревочном канате» и «неизбегаемое принудительное плавание с грузом».

У алкоголизированных животных контрольной группы, продолжительность периода плавания была ниже на $38 \%(p<0,05)$ и время удержания на канате меньше на $58 \%$ ( $p<0,05)$ соответственно, чем у интактных. У алкоголизированных животных, которым после отмены этанола вводили мефаргин, длительность периода плавания была на $47 \%(p<0,05)$ время удержания на канате - на 66\% (p<0,05) продолжительнее, чем у крыс контрольной группы. У самок, подвергавшихся ХАИ и получавших препарат сравнения фенотропил, длительность плавания, и время удержания на канате была на 90\% $(p<0,05)$ и 40\% соответственно больше, чем у животных контрольной группы. По результатам проведённых исследований можно сделать вывод о позитивном влиянии мефаргина на физическую работоспособность крыс, подвергнутых 6 месячной хронической алкогольной интоксикации.

\section{Литература:}

[1] Hammoud N., Jimenez-Shahed J. Clinics in Liver disease.2019, 23 (1): 141-155.

$$
-103-
$$

